\title{
UC-NRLF
}

|||||||||||||||||||||||||||||||||||||||||||||

\section{DEATH CAMAS}

Plants Poisonous to shoep and vattlo By C.E. Fleming \& N.F. Peterson Unir. of Norada Bulletin \#101 - Feb. 1921 


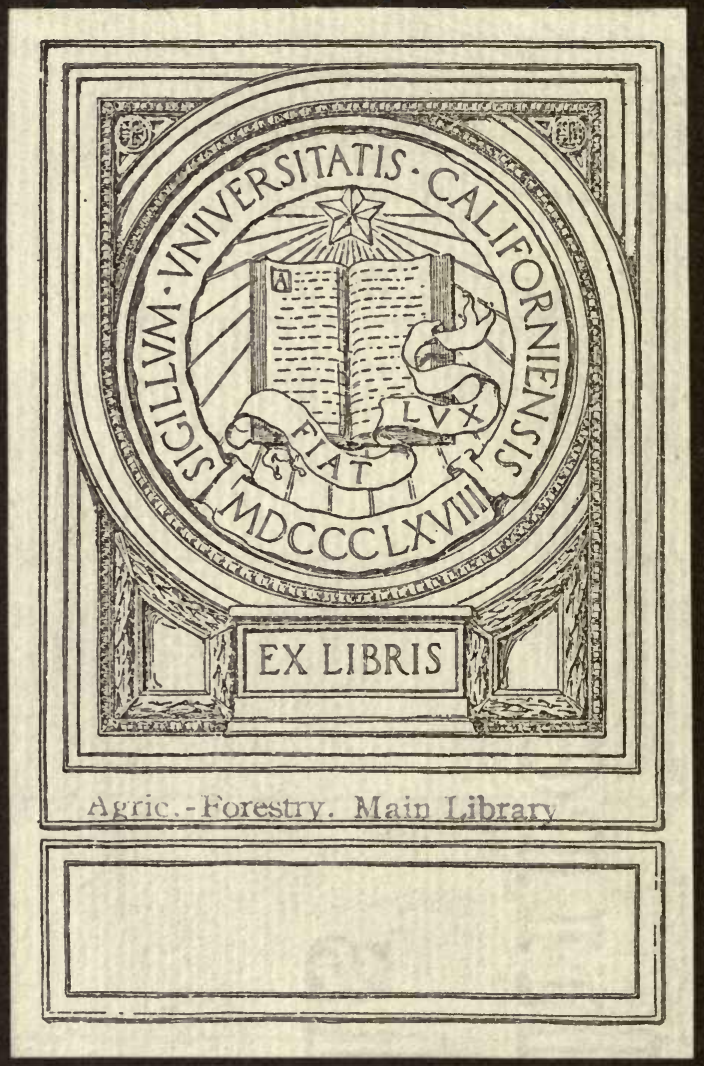




\section{THE UNIVERSITY OF NEVADA AGRICULTURAL EXPERIMENT STATION}

Bulletin No. 101

RENO, NEVADA

February, 1921

To diminish suffering and loss among domestic animals

\section{DEATH CAMAS}

7.

(Zygadenus paniculatus and Zygadenus venenosus)

Plants Poisonous to Sheep and Cattle

$\ddot{x}$

By

C. E. FLEMING and N. F. PETERSON

Of the Department of Range Management

Assisted by

M. R. MILLER

Of the Department of Chemistry

and

DR. L. H. WRIGHT

Of the Department of Veterinary Science

PUBLISHED BY THE UNIVERSITY OF NEVADA RENO, NEVADA

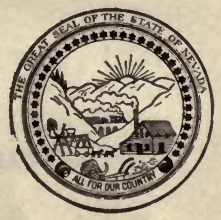

Printed at the

State Printing Office-Joe Farnsworth, Superintendent CARSON CITY, NEVADA 


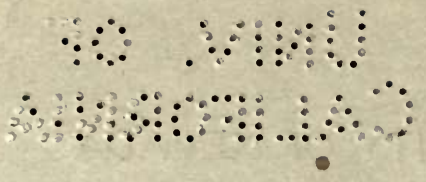

NEVADA AGRICULTURAL EXPERIMENT STATION

Hon. G. F. TALBOT (1931)

\section{BOARD OF CONTROL}

Hon. B. F. CURLER (1921)

Hon. Walter E. Pratt (1925)

Hon. Mrs. W. H. Hood (1927)

Hon. Miles E. North (1929)

\section{OFFICERS}

Walter E. Clark, Ph.D. . . . . . . . President of University UAROLYN BECK WITH Charles H. Gorman

SAMUEL B. Doten, M.A. • • - . - . DTAFF Director and Entomologist F. L. BIXBY, C.E. • • • • • • • • • • Irrigation (In cooperation with Bureau of Public Roads, U. S. D. A.)

Geo. Hardman, M.S. Charles E. Fleming, B.S.A. EDWARD RECORDS,V.M.D. LYMAN R.VAWTER, D.V.M. MADGE L. FINK, B.A. M. R. MILLER, B.S. Martha Ryan .

Assistant in Irrigation Range Management Veterinarian . . . . Pathologist - Secretary to Veterinary Department . . . . . . Chemist - Librarian and Secretary to Director 
 \\ STUDIES OF POISONOUS RANGE PLANTS IN THE UNIVERSITY OF NEVADA}

In undertaking the study of poisonous range plants, the Nevada Agricultural Experiment Station has planned a series of experiments to obtain information upon the following points: (1) the part of the plant which is poisonous, (2) the time of the year when it is dangerous, (3) the kinds of live stock poisoned, (4) the amount which must be eaten in order to cause illness or death, (5) the symptoms shown by the poisoned animals, (6) the conditions under which poisoning occurs, (7) methods of cure and treatment, (8) and methods of preventing poisoning.

In addition, studies are made of the post-mortem conditions shown by the poisoned animal, and of the chemical nature of the poisonous element found in the plant.

The basis of all these experiments consists of long series of feeding tests in which plants are brought fresh from the ranges to the University and are fed to range animals in pens where they are kept under close observation.

This bulletin is a report of the results obtained by feeding the plant known as death camas to range sheep and cattle.

S. B. DOTEN, Director, Nevada Agricultural Experiment Station.

UNIVERSITY OF NEVADA,

Reno, Nevada, January, 1921. 



\title{
SECTION I
}

\author{
DEATH CAMAS \\ Zygadenus paniculatus and Zygadenus venenosus \\ Plants Poisonous to Sheep and Cattle
}

\section{SUMMARY}

Death camas is a common poisonous plant of the sheep and cattle ranges in Nevada.

It is a low-growing bright-green plant related to the lilies and the onions. It comes up in the very early spring from a bulb buried eight inches or more in the ground. The bulb is much like an onion, but it has no onion odor, and is covered with a thin black coating. The leaves are long, slender, and grass-like. When the plants come up they look a little like Indian corn; but the leaf is narrower and more fleshy, and it has a distinct ridge or keel on the under side. At first there appears to be no stem; but later a flower stalk is sent up bearing a long cluster of pale yellow flowers.

The first green shoots come up early in the spring before there is grass on the range; and it is at this season that sheep and some cattle are poisoned.

It takes from one-fourth to one-half pound of the leaves to make a range sheep sick when the animal is confined in a pen; it takes a much larger dose, three pounds or more, to kill a sheep under the same conditions. On the range where sheep are driven hard and have no chance to rest and recover, smaller doses are probably often fatal.

On the whole, however, under ordinary range conditions it must be somewhat difficult for even one sheep in a band to obtain a fatal dose of the death camas leaves; and it is probable that many losses thought to have been caused by death camas were in reality caused by some other plant.

Sheep fatally poisoned by death camas froth at the mouth and slobber freely, and occasionally vomit. They grow weak in the hindlegs and stagger when made to walk. Within a few hours they become very dull and weak, standing with head and ears drooping and the back arched. Later, they go down and thereafter rise with difficulty if at all; becoming gradually weaker and usually dying within twentyfour hours from the time of feeding.

Cattle show much the same set of symptoms; but are apt not to froth at the mouth and drool as much as sheep. When in good condition they vomit so freely that they recover within two or three days.

In our experiments we did not succeed in killing any young cattle with death camas. Doses of three-eighths of a pound to two pounds made the animal sick, but caused prompt and profuse vomiting which brought about a fairly rapid recovery. On the range, death probably occurs only when half-starved cattle eat a considerable quantity under conditions where the system is too weak to throw off the poison or where weak animals, driven hard, are poisoned and get no chance to rest and recover.

There is no known remedy for death camas poisoning; and even if an antidote were discovered, it is not likely that it could be used suc- 

cessfully under range conditions. Since poisoning occurs only when weak and hungry animals are turned on to death camas ranges where there is no grass or other green feed, and since ordinarily both sheep and cattle will avoid death camas and eat almost anything else in preference, it is evident that the way to avoid poisoning is to keep halfstarved animals off death camas ranges and feed some hay until there is grass ; and then let the animals scatter out and browse at will, choosing their own forage.

The plants known as death camas have long been recognized as poisonous, being commonly considered as among the most dangerous plants of our western sheep and cattle ranges. Although discussed in nearly all publications dealing with poisonous plants, there is little if any definite information concerning the quantity required to make an animal sick or to cause death; and not much appears to be known about the classes of live stock poisoned, the conditions under which poisoning is most likely to occur, and methods of preventing losses. The experimental feedings and range observations presented in this bulletin were made for the purpose of obtaining exact information upon these points.

\section{Classes of Live Stock Poisoned.}

All of the range observations seem to show that more sheep than eattle or horses are poisoned by death camas. No losses of horses have been recorded by the Nevada Experiment Station; and it seems that cattle have been poisoned only when hungry and in poor condition in the spring of the year. Many of the losses on the open range which have been attributed to death camas may in reality have been caused by other plants not known at the time to be poisonous. In fact, a large number of range observations made by the Station show that the probability of poisoning by this plant is by no means so great as is commonly supposed. This side of the matter will be discussed at length farther on in this bulletin.

\section{Common Names.}

Death camas is the name by which these plants are commonly known on the range; but they are also called Mystery Grass, Poison Sego, Poison Onion, Lobelia, and Poison Camas.

In Nevada the most common kinds are the foot-hill death camas (Zygadenus paniculatus), and the meadow death camas (Zygadenus venenosus). The former grows in the foot-hills among sagebrush and other range browse; the latter is more plentiful in moist, grassy places. The foot-hill form is more common in Nevada, being found on most of the ranges in the northern part of the State.

\section{A Description of Death Camas.}

The group of closely-related plants known as death camas were formerly included in the lily family; but this family has recently been broken up by botanists who have placed the death camas in the "bunch-flower family"(Melanthacea).

The plant is erect, producing from two to eight fully formed grasslike leaves. It springs from a layered bulb set from two to eight inches deep in the soil. The bulbs vary in size according to the age of the plant; but they are commonly from one-half to one and one-fourth inches across and are covered by thin, black, papery coats or layers. The leaves are long, narrow, and curved; varying in length from six 
to eighteen inches; they are usually less than one-half inch wide; they look a good deal like coarse grass blades with a projecting ridge

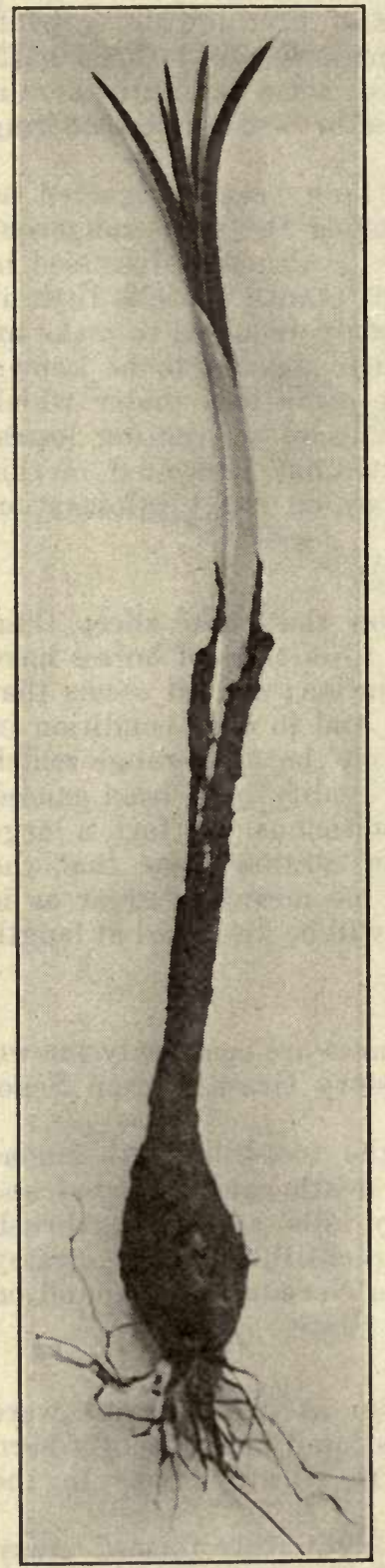

Figure 2. Foot-hill Death Camas, the Young Plant in Early Spring. like the keel of a boat on the under side. They are much thicker and more juicy than ordinary grass blades.

There is at first no well-defined stem, the leaves appearing to rise from near the surface of the ground. The flowers are greenish-yellow or whitish, about onefourth inch across; and are produced in a flower cluster from two to ten inches long. The lower flowers bloom first, and may produce seed pods before the upper flowers bloom. The seeds ripen in the summer; but lie dormant until the next spring, when they sprout and grow into tiny leafy plants. These soon develop small bulbs which may not be any larger than a pea by the end of their first summer's growth. It takes a new plant several seasons to form a bulb sufficiently large to begin to produce flowers and seeds.

The foot-hill death camas differs from the meadow form by having a larger and longer bulb, lying deeper in the soil, usually at a depth of from five to eight inches; while the bulb of the meadow form is smaller and much shorter and is rarely found more than two inches deep in the ground. The foot-hill death camas is also a much larger plant; its flower cluster is branched at the base, while the much shorter cluster of the meadow form is unbranched.

\section{Plants Commonly Mistaken for Death Camas.}

Death camas is most commonly confused with the wild onion, although it has no onion odor. When in bloom the two are easily distinguished, for all of the flowers of the onion cluster grow out from the tip of the flower stem, while the flowers of the death camas grow along the sides of the stem as in Figure 4.

\section{Where the Death Camas Grows.}

Death eamas plants may be found on practically every stock range in Nevada, growing more abundantly in the northern half of the State than in the southern. The ground on which the death camas grows is always quite moist in the spring of the year; and the typical grazing types in which they are found 
are: (1) sagebrush, (2) grass, (3) semimeadow areas, and (4) typical weed ranges where the vegetation consists largely of showy flowering plants. They do not grow in the shade under standing timber. They are found on practically all of the mountain foot-hills, the high open mountain park areas, and in the sagebrush country of northern and western Nevada.

\section{The Time of Year When Growth Begins.}

The time when death camas starts to grow in the spring varies with the season and also with different exposures and different soils; the green shoots are sometimes found as early as the middle of March.

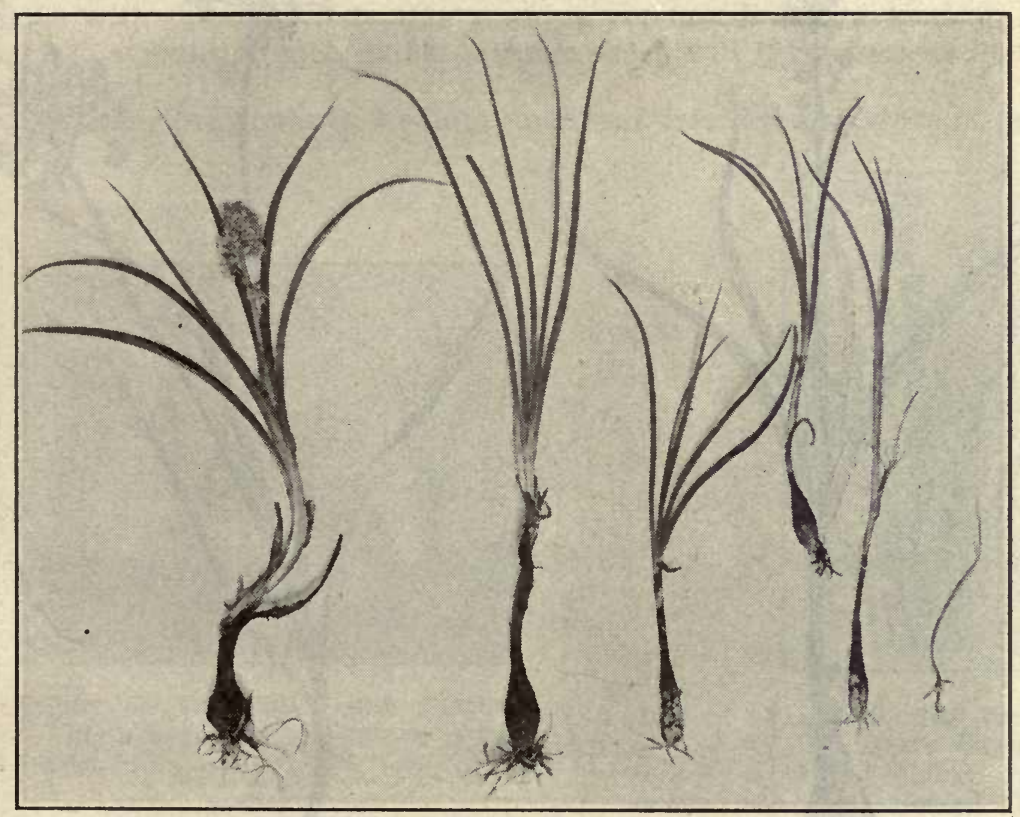

Figure 3. Foot-Hill Death Camas. Plants in various stages of growth, from seedlings to mature plant in bloom.

The plants make their appearance first on sandy soils and on southern exposures. On the dark loamy and clay soils their growth is much retarded; probably because these soils are moist and consequently warm up less readily. If the weather is fairly warm the death camas will begin to grow from ten days to two weeks after the snow melts out in the spring; and the leaves are soon high enough to cause loss. By the latter part of June on the lower ranges, the plant has usually died down.

\section{How the Flavor of Death Camas Affects the Probability of Poisoning.}

All species of death camas which grow in Nevada have a bitter flavor and are extremely distasteful to cattle and sheep. In all our feeding 
tests it was practically impossible to get either sheep or cattle to eat this plant readily, even after going hungry for two or three days. When a hungry animal was first fed, a few mouthfuls would be eaten; but almost as soon as the plant juices came in contact with the mouth the animal would begin to wrinkle its nose and move its tongue in such a manner as quickly to get rid of what was in its mouth.

In order to get any large number of plants into an animal it was necessary to resort to forced feedings, which consisted mainly in placing the ground leaves so far back in the animal's mouth that it had to swallow what was given it. When this plant, mixed with palatable

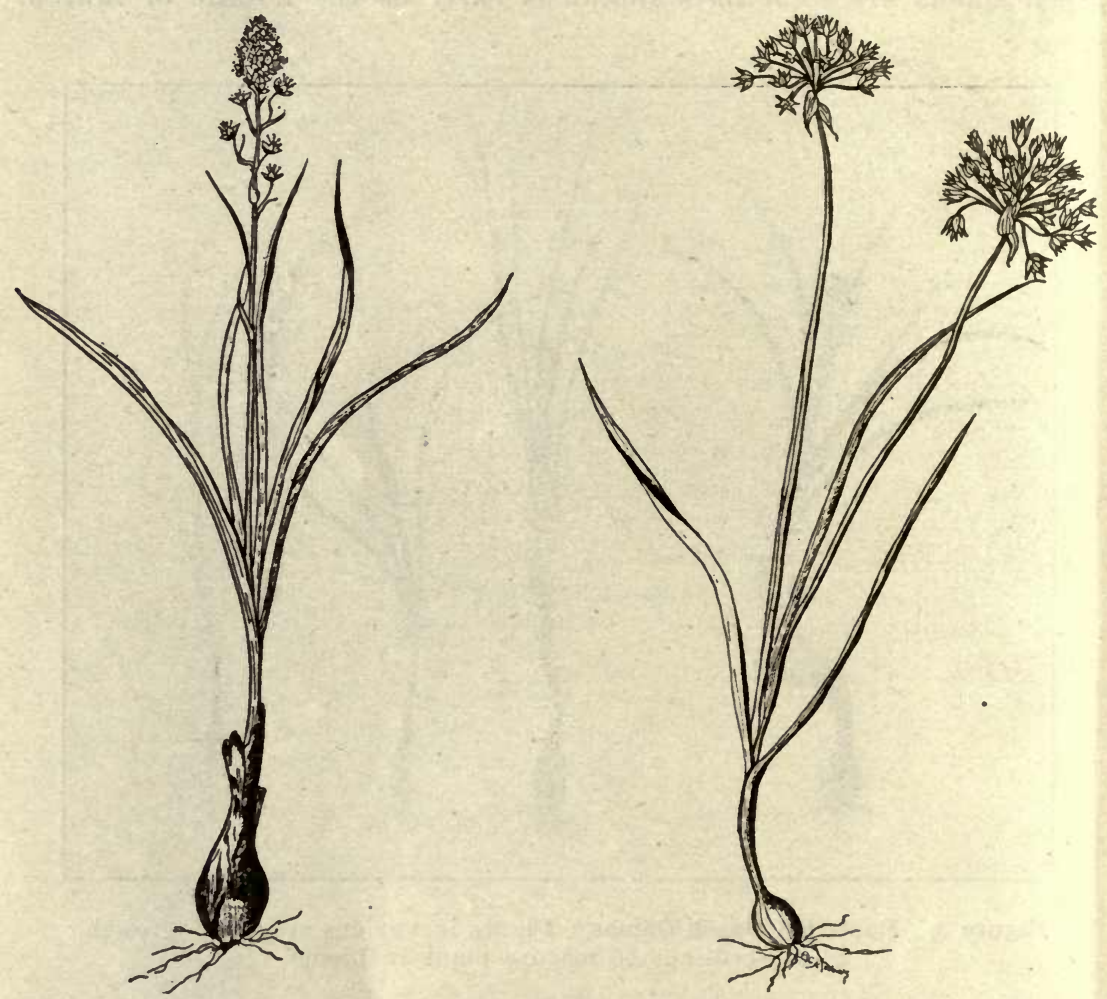

Figure 4. Foot-Hill Death Camas (on left) and Wild Onion. Notice the difference in the arrangement of the flowers on the stem. The flowers of death camas are scattered along the sides of the stem; those of wild onion form a round cluster at the end of the stem.

weeds and grasses, was fed to hungry animals they would sort out the grasses and weeds and eat them, avoiding the death camas wherever possible. This shows clearly how sheep and cattle dislike this poisonous plant and try to avoid eating it.

On many of the grazing ranges in the western part of Nevada, sheep have been closely observed while grazing on ground supporting death camas, with weeds, browse, and a scattering stand of grasses. The sheep nibbled weeds and grasses all around the death camas, leaving it almost untouched. Naturally, no losses occurred under these conditions. 
On several of these ranges it was noticed that the death camas plants had been grazed by some animal. A study of conditions on near-by ranges, where it was known that there had been no live stock that season, revealed the fact that a number of rodents, common ground squirrels among others, were eating the leaves and digging up the bulbs. Ordinarily, if there had been sheep on these ranges and poisoning had occurred, it would have been seen that the death camas plants had been grazed; and they would have been blamed for the losses.

A series of similar observations were made on Peavine Mountain, near Reno by J. A. Longyear who states that the tops of death camas plants are nibbled rather freely by ground squirrels.

Because of the fact that in the experimental work it took a large quantity of death camas to kill a sheep, a series of feeding tests were made with the most palatable young green weeds and grasses to find out the amount of such plants a range sheep will eat before its hunger is satisfied.

Two yearling lambs in medium condition were fed a mixture of green

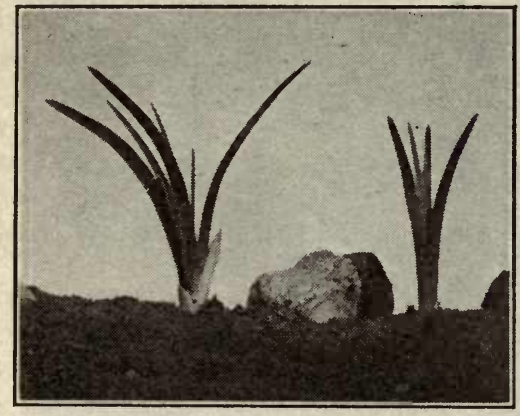

Figure 5. Foot-Hill Death Camas. Plants beginning growth in early spring.

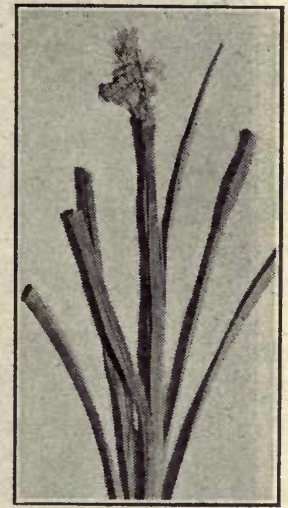

Figure 6. The FootHill Death Camas. This plant has been nibbled by ground squirrels.

grasses and weeds. These animals were fed during a series of days all they would eat in the forenoon and afternoon. The average consumption of weeds and grass was four and one-half pounds on each halfday, or nine pounds per day.

Two old ewes weighing 80 and 90 pounds respectively were put to the same test as the lambs; and it was found that on the average each would eat a little over eight pounds daily. These tests probably show quite accurately the quantity of green feed eaten by a range sheep in a single day.

With death camas the experimental feeding tests showed that the smallest amount which will make a sheep sick is between one-fourth pound and one pound. Amounts of one-fourth to two and one-half pounds in each feeding made the sheep sick; but none died from the direct effects of the poisoning. However, two were so weakened that they died later; one from inflammation and ulceration of the fourth 
stomach, the other from pneumonia. Quantities of three pounds or more killed the animals in all cases, with the exception of a single sheep which appeared far more resistant to poisoning than the average animal.

When we compare the capacity of a sheep's stomach, approximately four and one-half of green grass and weeds at a single feeding, with the quantity of death camas required to kill, approximately three pounds or more; then it would appear that the sheep would have to graze very largely on death camas in order to secure a fatal dose.

In order to get a clear idea of how thick a stand of death camas there is on the range early in the spring when the danger is greatest, squarerod plots were laid out where death camas (Zygadenus paniculatus) appeared most abundant on the foot-hills southwest of Reno. On April 12, 1918, 32 plants, all that grew on one square rod, were cut off at a height of three-quarters inch above the ground. The total weight

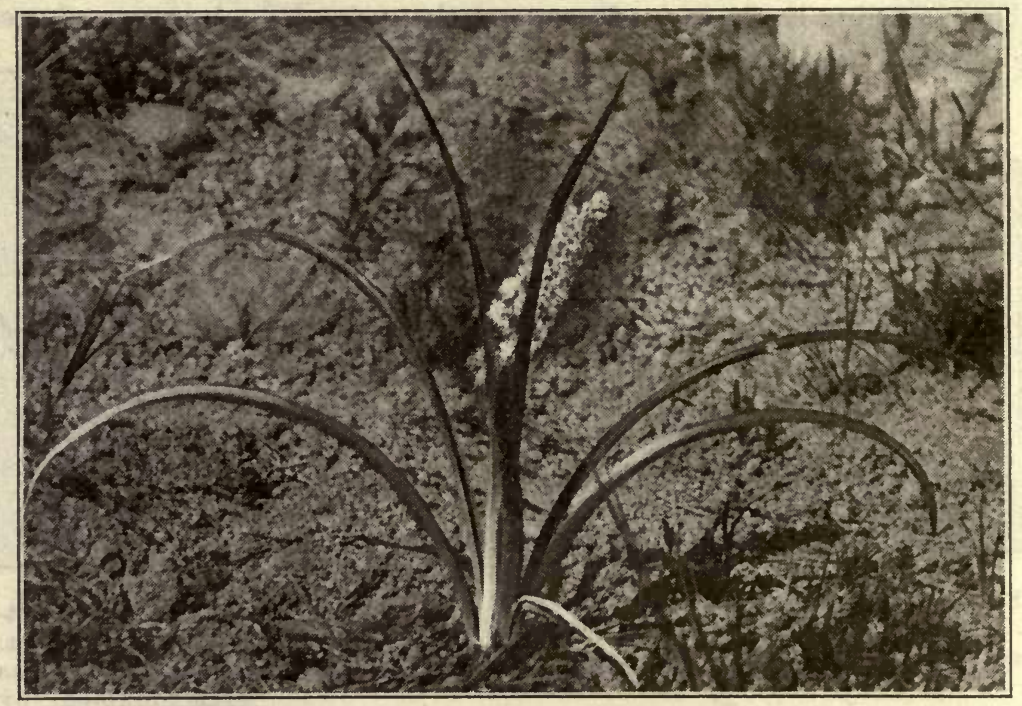

Figure 7. Foot-Hill Death Camas. The leaves appear to spring directly from the ground without any stem.

was 32.8 grams, or a little more than an ounce. On April 15, 52 plants were cut from two square rods and the total weight of leaves cut was 28.6 grams per square rod, or approximately one ounce. At this rate it would take sixteen square rods to produce a single pound of the plant. The leaves at this time were from four to eight inches high.

On all of these plots there was a far heavier stand of death camas than would ordinarily be found on any of the ranges in Nevada. If the plants really grew as thickly on the range as on these selected plots, and if they had reached a height of from four to eight inches, then each acre would produce from 10 to 12 pounds of death camas, enough to poison fatally some three or four sheep. The death camas was cut and weighed at a time of year when all other green vegetation was very scarce, and the likelihood of poisoning was greatest.

On May 17, 1918, when other range vegetation was quite abundant, 
17 death eamas plants, all that grew on a square rod, were elipped three-fourths of an inch from the surface of the ground; they weighed 4.8 ounces, somewhat more than one-fourth pound. The plants were then in full bloom, some of them going to seed. At this rate and at this time of year an acre would produce approximately 48 pounds of death camas, enough to poison fatally about 16 head of sheep. However, the plant does not grow as thickly as this uniformly over any sheep range. The square-rod plots were selected areas, chosen because they supported an unusual number of plants.

Foot-Hill Death Camas(Zygadenus paniculatus)Feeding Experiments with Sheep.

In the course of the years 1918 and 1919,69 feedings were made to sheep. Most of these feedings were of leaves, only a few feedings being made of the flower-heads, seed-heads, and bulbs. The results of these feedings are condensed in Table I.

The results of the experiments presented in this table may be summarized as follows:

(1) None of the nine feedings of $\frac{1}{8}$ pound each had any appreciable effect upon the animal, indicating that this quantity of the plant is practically harmless ; (2) out of the 16 feedings of $\frac{1}{4}$ pound of the tops, six tests produced no visible symptoms, while 10 made the animals appreciably sick. These feedings show that if sheep in a range flock eat as little death eamas as $\frac{1}{4}$ pound each, trouble may possibly follow.

A single feeding of $\frac{1}{4}$ pound of the bulbs made one sheep sick, but in a few hours it had completely recovered. It takes several plants to make $\frac{1}{4}$ pound of the bulbs, more plants in fact than a sheep could possibly ever pull up; so the bulbs as a poisonous part of the plant may be completely disregarded.

(3) Nine out of 12 feedings of $\frac{1}{2}$ pound of the tops produced typical symptoms of poisoning, while three apparently had little effect upon the animals. A half-pound of the tops will generally make a sheep sick; any larger quantity will almost always cause severe poisoning.

(4) Four out of five feedings of $\frac{3}{4}$ pound each made the animals sick. These sheep were much more seriously affected than those fed $\frac{1}{2}$ pound each.

(5) Of seven feedings of one pound each, six caused severe poisoning while one had no effect. Apparently one pound is as much as any sheep can eat without danger of serious poisoning.

(6) Four feedings of from $1 \frac{1}{4}$ to $1 \frac{1}{2}$ pounds all caused severe but not fatal poisoning.

(7) Five feedings of quantities varying between $1 \frac{3}{4}$ pounds and $2 \frac{1}{2}$ pounds caused very severe poisoning, resulting in death in two cases.

(8) All feedings of three pounds each resulted fatally. However, sheep No. 18 was twice fed $3 \frac{1}{2}$ pounds without a fatal result, although the animal was severely poisoned and was sick for more than a day each time. This animal appeared to be very resistant to poisoning by death camas; later, in tests with other plants, she showed the same resistance to poisoning.

(9) Three feedings of four pounds of the tops all eaused death. It seems fair to assume that under ordinary conditions no sheep can eat such a quantity of death eamas and live. Still, four pounds is a far greater quantity than any sheep is likely ever to find on the range.

(10) Of three feedings of quantities of seed-heads varying between 
TABLE I

Foot-Hill Death Camas ( $Z$. paniculatus). The Fresh Green Plant Fed to Sheep.

\begin{tabular}{|c|c|c|c|c|c|c|c|}
\hline Ini & $\begin{array}{l}\text { Veight } \\
\text { lbs. }\end{array}$ & ate fed & Time fed & & $\begin{array}{c}\text { Time symptom } \\
\text { appeared }\end{array}$ & $\begin{array}{l}\text { ne of death } \\
\text { recovery }\end{array}$ & Final result \\
\hline $\begin{array}{l} \\
\end{array}$ & 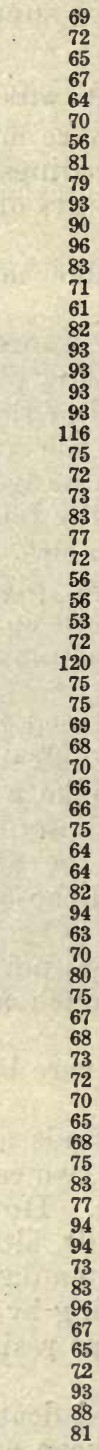 & 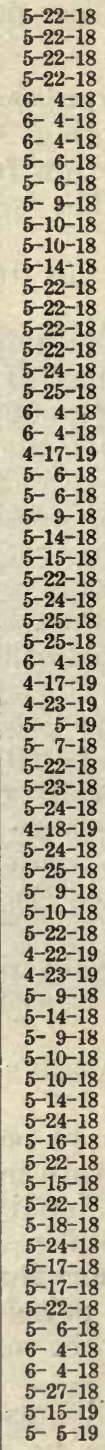 & 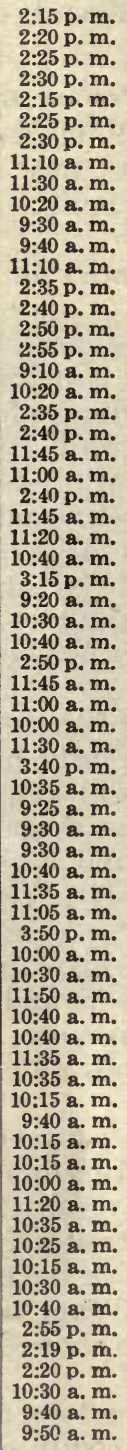 & 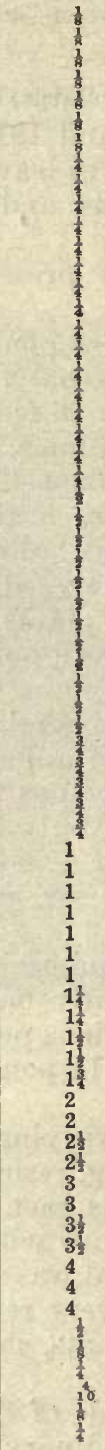 & 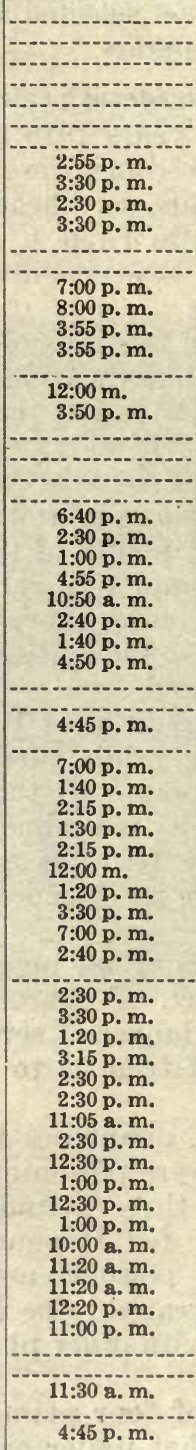 & 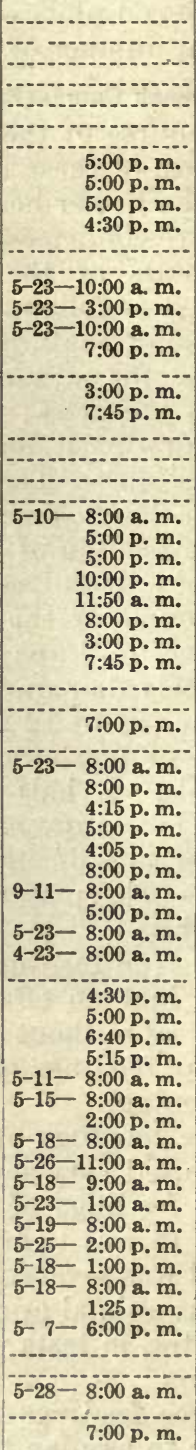 & 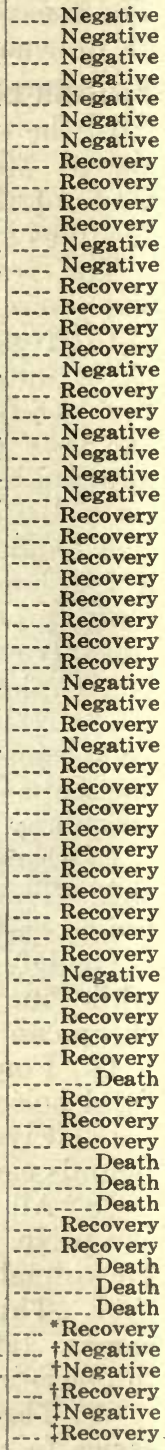 \\
\hline
\end{tabular}

*Flower heads fed. †Seed heads fed. \$Bulbs fed. 
$\frac{1}{8}$ and $4 / 10$ of a pound, one caused sickness and two were without result. Apparently the green seed-heads are about as poisonous as the leaves and stems. The number of tests, however, was not great enough to prove this conclusively. As a cause of poisoning in range sheep it is believed that the seed-heads of death camas are of very little importance.

\section{Symptoms of Poisoning in Sheep by Foot-Hill Death Camas.}

Small doses, from $\frac{1}{4}$ to $\frac{3}{4}$ of a pound, cause salivation or slobbering in nearly every case. A few cases show nausea and vomiting; there is often a marked increase in the rate of respiration sometimes amounting to panting. The breathing is very irregular; for a time it is rapid, then very slow. In some eases there is a muscular weakness, which is most noticeable in the hind-legs.

With larger doses, from one to two pounds, there is in addition to the above symptoms a period of dullness during which the animal stands with the back arched and the head and ears drooping. With still larger doses the animal becomes so weak as to be unable to rise.

In some cases the mucous membrane of mouth and tongue appeared blue; and two sheep showed such a spasmodic twitching of the muscles as occurs in strychnine poisoning.

Time Necessary for Symptoms of Poisoning to Appear.

The time which elapsed from the time of feeding until symptoms appeared varied from one to seven hours, the average being three hours and ten minutes. The time was slightly less for the larger doses. With doses of less than two pounds the time averaged three hours, twenty-two minutes; with doses of three pounds or more the average was two hours, twenty-five minutes.

\section{Length of Time the Poisoned Sheep Were Sick.}

The length of time through which the sheep remained sick was quite variable. After doses of $\frac{1}{4}$ pound to two pounds the animals were sick for from one to eighteen hours, averaging about five or six hours. As several of these sheep recovered during the night, we do not know exactly how long they were sick. Most of the sheep which died from the direct effects of death camas poisoning were sick from twenty to twenty-five hours; and one was down and unable to rise for neârly three days before it died.

Some Typical Cases of Death Camas Poisoning in Sheep.

Case 1. A yearling wether weighing 81 pounds was fed $\frac{1}{4}$ pound of the leaves of death camas at $11: 10 \mathrm{a}$. m. May 5, 1918. At 2:55 p. m. it began to froth at the mouth and made attempts to vomit. The breathing was very irregular, alternately rapid and slow. At 4:30 p. m. the animal seemed to be getting better and by $5 \mathrm{p}$. $\mathrm{m}$. it appeared to have recovered completely.

Case 2. About one month later, on June 4, 1918, the same sheep, now weighing 93 pounds, was fed $\frac{1}{4}$ pound at $2: 35 \mathrm{p}$. m. At $3: 50 \mathrm{p}$. m. it began slobbering; and at $4: 05 \mathrm{p}$. m. it was nauseated and began to vomit. The breathing was at first fast and shallow, then slow and full, with occasional slight pauses. By $4: 30$ it had vomited an amount estimated at $\frac{3}{4}$ of a quart. Vomiting ceased soon afterward and by $4: 50$ the sheep was much better. When next' observed, at $7: 45 \mathrm{p}$. m., it was eating hay and appeared to have fully recovered. 
Case 3. A yearling wether weighing 56 pounds was fed $\frac{1}{2}$ pound of death camas leaves at $3: 15 \mathrm{p}$. m. May 22,1918 . At $4: 35$ it was froth-

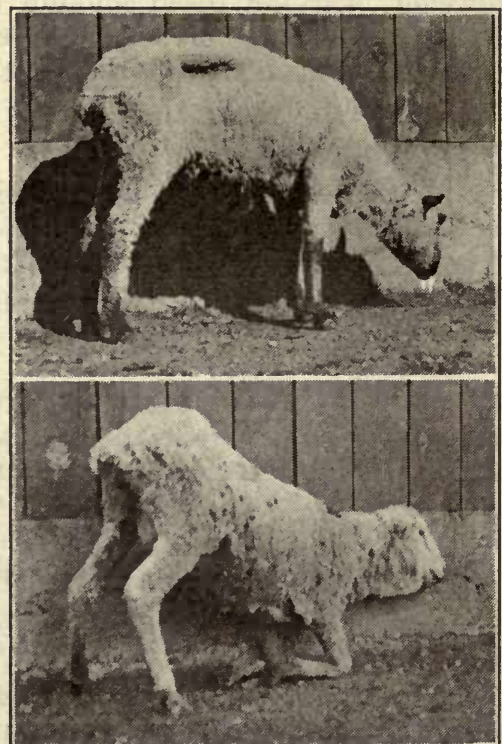
ing at the mouth and trying to vomit. At $4: 40$ it was vomiting freely. At 7 p. m. it was still frothing at the mouth, but had ceased vomiting and was getting better. At 8 p. m. it seemed to have recovered. At $10 \mathrm{p}$. $\mathrm{m}$. it was again slobbering a little. Next morning at 8 o'clock it had fully recovered.

Case 4. A yearling wether fed $\frac{3}{4}$ pound of the leaves at $9: 25 \mathrm{a}$. $\mathrm{m}$. May 24, 1918, began slobbering a little at $2: 15 \mathrm{p}$. m. This gradually increased, and at $3: 20$ it was foaming freely at the mouth. At $4 \mathrm{p}$. m. it was still slobbering a little; but at $4: 15$ it began eating grass and seemed to have recovered fully. No other symptoms were noted.

Case 5. A ewe weighing 75
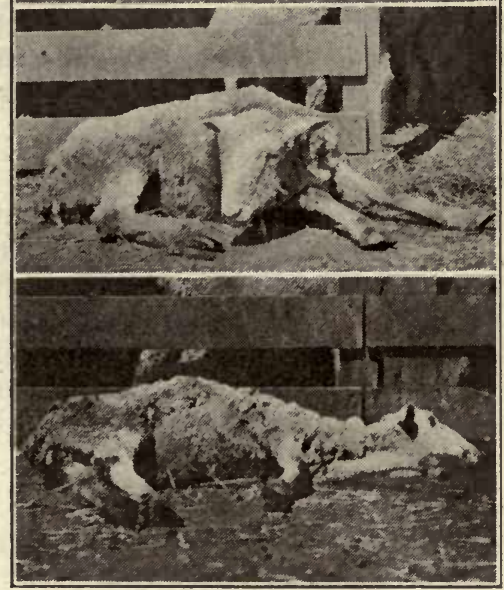
pounds was fed $1 \frac{1}{4}$ pounds of death camas at $11: 50$ a. m. At $2: 30$ this sheep was grinding its teeth and slobbering freely. At $3: 40$ it was dull and stood with the head and ears drooping, still frothing freely at the mouth. At 4:30 the animal appeared to have nearly recovered, and was nibbling at feed.

Case 6. A ewe weighing 68 pounds was fed $1 \frac{1}{2}$ pounds of death camas at 10:40 a. m. May 9, 1918 . It began to froth at the mouth at $1: 20$ p. m. At about $1: 30$ it vomited a considerable amount. At $2: 30$ it was slobbering freely, and

Figure 8. Death Camas Poisoning. stood with drooping head; showing a decided weakness in the hind legs. At $3: 30$ it was salivating less freely, but still stood with head drooping. At 4:30 it was getting better; but was still slobbering a little, and refused to eat. At 6:40 it appeared to have fully recovered.

Case 7. A ewe weighing 83 pounds was fed three pounds of death camas leaves on May 15, 1918, at $10 \mathrm{a}$. m. At 1:30 p. m. it was slobbering freely, was weak, and staggered when made to move. The breathing was labored, and at times the animal vomited. These symptoms continued, the animal growing worse until $3 \mathrm{p} . \mathrm{m}$. and becoming weak enough by $4 \mathrm{p}$. m. to stagger when walking; it was then so weak 
that it could easily be pushed over. The mucous membranes of the mouth and tongue were bluish. At 7:30 p. m. it seemed better, and did not appear so weak. At 9 a. m. next day it was down flat on the side and unable to rise. At $11 \mathrm{a}$. $\mathrm{m}$. it had twitching movements of the muscles similar to those in strychnine poisoning. The animal remained down all that day. Next morning it was still down and appeared to be getting weaker; the breathing was labored and was accompanied by peculiar grunts. At 9 a. m. on the 18 th it was found dead, but still warm.

Case 8. A ewe weighing 77 pounds was fed three pounds of death camas at 11:20 a. m. May 22, 1918. At 12:30 it was frothing at the mouth; by $1: 30$ it was frothing freely at the mouth and vomiting; these symptoms continued until about $2: 30$. By $2: 50$ the animal was weak in the hind legs and staggered when made to walk. The animal continued to get worse, and by $4 \mathrm{p}$. m. was very weak and dull, standing with head and ears drooping and the back arched. At $4: 30$ it vomited again. At 7 a. $m$. the animal was very dull, and staggered when made to move. It continued to grow worse until $10 \mathrm{p}$. m. Next morning, at $8 \mathrm{a} . \mathrm{m}$. it was very weak and unable to get up. It remained in this condition all the forenoon; and died quietly at 1:30 p. m.

Meadow Death Camas (Zygadenus venenosus) Feeding Experiments with Sheep.

Only three feeding tests were made, as the plant is not at all abundant on the ranges in western Nevada; and material for the tests was necessarily limited. It is much less important on Nevada ranges than the foot-hill death camas. The results of the three feedings are summarized in Table II.

TABLE II

Meadow Death Camas ( $Z$. venenosus). The Green Leaves and Flowers Fed to Sheep.

\begin{tabular}{|c|c|c|c|c|c|c|c|}
\hline $\begin{array}{l}\text { Animal } \\
\text { No. }\end{array}$ & $\begin{array}{l}\text { Weight } \\
\text { lbs. }\end{array}$ & Date fed & Time fed & $\begin{array}{l}\text { Amount } \\
\text { fed, lbs. }\end{array}$ & $\begin{array}{c}\text { Time symptoms } \\
\text { appeared }\end{array}$ & $\begin{array}{l}\text { Time of death } \\
\text { or recovery }\end{array}$ & Final result \\
\hline $\begin{array}{l}37 \\
37 \ldots \ldots \\
62 \ldots\end{array}$ & $\begin{array}{r}90 \\
93 \\
101\end{array}$ & $\begin{array}{l}6-9-19 \\
6-11-19 \\
6-26-19\end{array}$ & $\begin{array}{l}9: 45 \text { a. } \mathrm{m} . \\
10: 50 \text { a. m. } \\
11: 00 \text { a. m. }\end{array}$ & $1^{\frac{1}{2}}$ & $\begin{array}{l}\text { 1:40 p. m. } \\
11: 50 \text { a. m. }\end{array}$ & $\begin{array}{r}\text { 5:00 p. m. } \\
\text { After 11:00 p. m. }\end{array}$ & $\begin{array}{l}\text { Negative } \\
\ldots-\text { Recovery } \\
\ldots \ldots \text { Death }\end{array}$ \\
\hline
\end{tabular}

The experiments summarized in Table II show that this plant is poisonous and that amounts of one pound or more will cause serious poisoning in sheep. The symptoms produced by this plant are almost identical with those described for the foot-hill species, as will be seen from the following typical cases:

\section{Typical Cases of Poisoning in Sheep, Meadow Death Camas.}

Case 1. A ewe weighing 93 pounds was fed one pound at $10: 50 \mathrm{a} . \mathrm{m}$. At $1: 40$ p. m. it was foaming at the mouth. At 2:40 it was chewing cud, but still foaming at the mouth. At $5 \mathrm{p}$. m. it appeared to have recovered.

Case 2. On June 26, 1919, a ewe weighing 101 pounds was fed two pounds of the plant at $11 \mathrm{a}$. m. At 11:50 it was foaming at the mouth and vomiting. At $1 \mathrm{p} . \mathrm{m}$. the respiration was rapid and irregular, varying from 55 to 70 per minute. It still frothed freely at the mouth, the froth being seattered all over the pen. By 4:15 it was very weak, staggered when walking, trying to vomit. The animal then appeared 


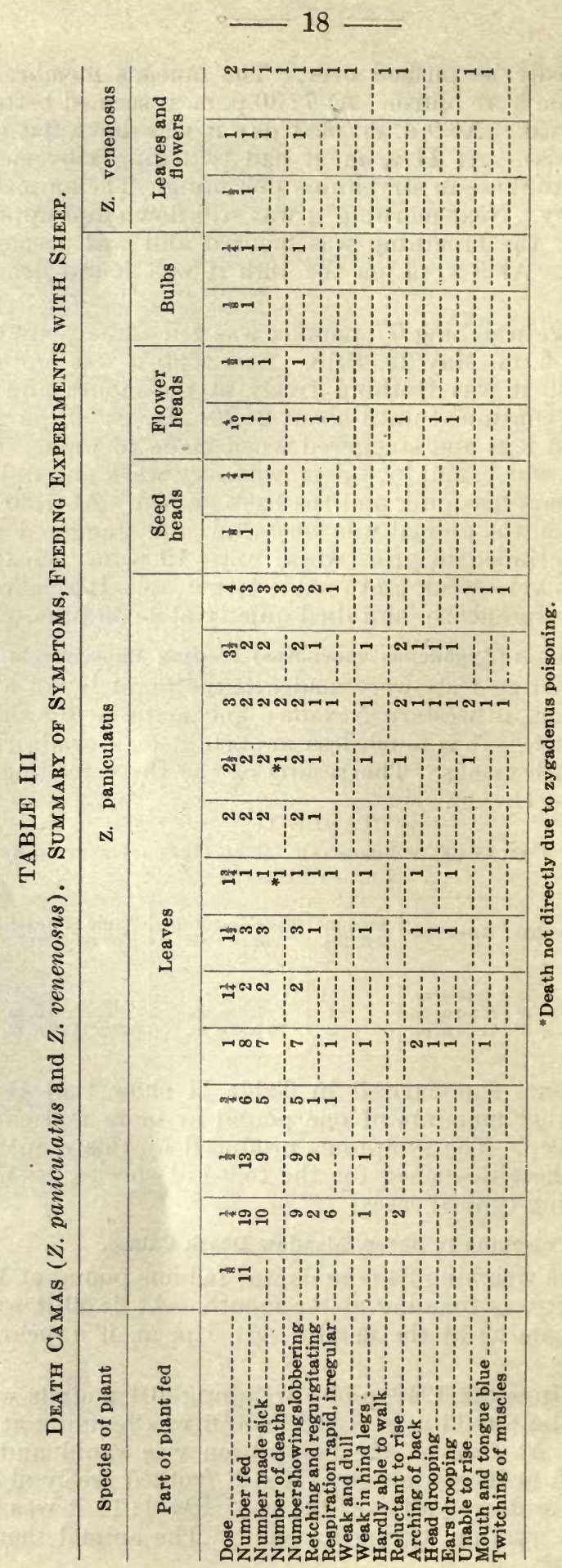


to be strangling, perhaps due to froth getting into the windpipe. It fell at $4: 30$ and could not get up again; at $4: 45$ it got up, but could barely walk. At $7 \mathrm{p}$. m. it was down and could not be induced to rise. It continued to get weaker and duller until 10:30 p. m., when the observer left for the night. The animal probably died soon afterward; as it was dead, cold and stiff, at 8 the following morning.

\section{A Table of Symptoms of Death Camas Poisoning in Sheep.}

Table III gives in very condensed and concrete form the effects of various quantities of death camas ( $Z$. paniculatus and $Z$. venenosus) when fed to sheep (see page 18).

Feeding the Green Foot-Hill Death Camas to a Ewe with Suckling Lamb.

Reports from various sources made it seem possible that suckling lambs might be poisoned by alkaloids secreted in the mother's milk when the ewes fed upon this plant, and before the lambs were old enough to nibble at it. To test this matter, a ewe with a suckling lamb was fed the foot-hill death camas under the conditions listed in Table IV.

TABLE IV

Foot-Hill Death Camas (Z. paniculatus). The Fresh leaves Fed to a Ewe WITH SUCKLING LAMB.

\begin{tabular}{|c|c|c|c|c|c|c|c|c|}
\hline $\begin{array}{c}\text { Animal } \\
\text { No. }\end{array}$ & Date & Time fed & $\begin{array}{l}\text { Amt. } \\
\text { fed, } \\
\text { lbs. }\end{array}$ & $\begin{array}{l}\text { Weight } \\
\text { lbs. }\end{array}$ & $\begin{array}{c}\text { Time } \\
\text { symptoms } \\
\text { appeared }\end{array}$ & $\begin{array}{l}\text { Time of } \\
\text { recovery }\end{array}$ & $\begin{array}{c}\text { Effect on } \\
\text { ewe }\end{array}$ & $\begin{array}{c}\text { Effect on } \\
\text { lamb }\end{array}$ \\
\hline $37 \ldots$ & $\begin{array}{l}4-1-19 \\
4-2-19 \\
4-3-19 \\
4-4-19 \\
4-9-19 \\
4-10-19 \\
4-11-19 \\
4-16-19 \\
4-17-19 \\
4-18-19 \\
4-19-19 \\
4-22-19\end{array}$ & $\begin{array}{l}\text { 1:30 p. m. } \\
\text { 3:30 p. m. } \\
\text { 1:30 p. m. } \\
\text { 1:30 p. m. } \\
\text { 9:00 a. m. } \\
\text { 8:40 a. m. } \\
\text { 9:00 a. m. } \\
\text { 8:40 a. m. } \\
\text { 8:30 a. m. } \\
\text { 9:30 a. m. } \\
\text { 9:00 a. m. } \\
\text { 10:00 a. } \mathrm{m} .\end{array}$ & $\begin{array}{r}\frac{1}{8} \\
\frac{1}{8} \\
\frac{1}{8} \\
\frac{1}{8} \\
\frac{1}{4} \\
\frac{1}{4} \\
\frac{1}{4} \\
\frac{1}{2} \\
1 \\
1 \frac{3}{4} \\
1 \frac{1}{2} \\
1 \frac{1}{2}\end{array}$ & 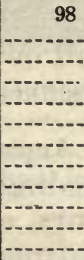 & 11:30 a. m. & $\begin{array}{r}\text { 4:00 p. m. } \\
\text { 11:00 a. m. } \\
\text { 4-20-8:00 a. m. } \\
\text { 2:00 p. m. }\end{array}$ & $\begin{array}{l}\text { Negative } \\
\text { Negative.. } \\
\text { Negative. } \\
\text { Negative. } \\
\text { Negative. } \\
\text { Negative.. } \\
\text { Negative. } \\
\text { Negative. } \\
\text { Recovery . } \\
\text { Recovery . } \\
\text { Recovery.. } \\
\text { Recovery . }\end{array}$ & $\begin{array}{l}\text {--Negative } \\
\text {-Negative } \\
\text {--Negative } \\
\text {--Negative } \\
\text {--Negative } \\
\text {--Negative } \\
\text {--Negative } \\
\text {--Negative } \\
\text {--Negative } \\
\text {--Negative } \\
\text {--Negative } \\
\text {-_Negative }\end{array}$ \\
\hline
\end{tabular}

The tests recorded in Table IV show that although the ewe was fed amounts varying from $\frac{1}{8}$ pound to $1 \frac{1}{2}$ pounds and was made sick four times, still the suckling lamb was not affected during any of the twelve feedings of its mother.

In the case of the ewe these feedings would also seem to indicate that there is little or no tendency for a sheep to become immune to the poisonous effects of death camas after feeding repeatedly upon it.

\section{Feeding Green Foot-Hill Death Camas to Cattle.}

Table V summarizes the results of eighteen tests in which the fresh green plants were fed to cattle (see next page).

It appears from this table that cattle are quite susceptible to the poisonous principle of the foot-hill death camas. Out of the eighteen feedings, ten made the animal sick; but no deaths occurred. It was almost impossible to get cattle to eat more than two pounds of the plant; because they soon became so violently sick that they vomited up all the material eaten. Two small feedings of $\frac{1}{4}$ pound each had no apparent effect upon the animals fed; but quantities of from $\frac{3}{8}$ of a pound to two pounds usually caused symptoms of poisoning. In some instances poisoning was quite severe, reducing for several days the vigor and strength of the animal. 
TABLE V

Foot-Hill Death Camas (Z. paniculatus). The Green Ieaves fied to Catrte.

\begin{tabular}{|c|c|c|c|c|c|c|c|}
\hline$\underset{\text { No. }}{\text { Animad }}$ & $\begin{array}{l}\text { Weight } \\
\text { lbs. }\end{array}$ & Date fed & Time fed & $\begin{array}{l}\text { Amount } \\
\text { fed, lbs. }\end{array}$ & $\begin{array}{c}\text { Time symptoms } \\
\text { appeared }\end{array}$ & $\begin{array}{l}\text { Time of death } \\
\text { or recovery }\end{array}$ & Final result \\
\hline 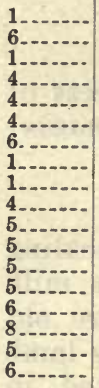 & $\begin{array}{l}137 \\
203 \\
137 \\
165 \\
165 \\
165 \\
203 \\
137 \\
143 \\
150 \\
208 \\
208 \\
208 \\
208 \\
193 \\
220 \\
208 \\
193\end{array}$ & $\begin{array}{l}4-8-19 \\
4-12-19 \\
4-10-19 \\
4-10-19 \\
4-15-19 \\
4-8-19 \\
4-10-19 \\
4-12-19 \\
4-16-19 \\
4-25-19 \\
4-10-19 \\
4-16-19 \\
4-8-19 \\
4-12-19 \\
4-16-19 \\
4-14-19 \\
4-19-19 \\
4-25-19\end{array}$ & $\begin{array}{l}8: 00 \text { a. } \mathrm{m} . \\
\text { 8:45 a. } \mathrm{m} . \\
8: 30 \text { a. } \mathrm{m} . \\
9: 00 \text { a. } \mathrm{m} . \\
9: 00 \text { a. } \mathrm{m} . \\
8: 30 \text { a. } \mathrm{m} . \\
9: 45 \text { a. } \mathrm{m} . \\
\text { 8:30 a. } \mathrm{m} . \\
9: 00 \text { a. } \mathrm{m} . \\
10: 50 \text { a. } \mathrm{m} . \\
10: 20 \text { a. } \mathrm{m} . \\
10: 20 \text { a. } \mathrm{m} . \\
9: 00 \text { a. } \mathrm{m} . \\
10: 00 \text { a. } \mathrm{m} . \\
11: 30 \text { a. } \mathrm{m} . \\
10: 20 \text { a. } \mathrm{m} . \\
10: 00 \text { a. } \mathrm{m} . \\
9: 30 \text { a. } \mathrm{m} .\end{array}$ & $\begin{array}{l}\frac{1}{4} \\
\frac{1}{3} \\
\frac{3}{8} \\
\frac{3}{8} \\
\frac{3}{8} \\
\frac{1}{2} \\
\frac{1}{2} \\
\frac{1}{2} \\
\frac{1}{2} \\
\frac{1}{2} \\
\frac{1}{2} \\
\frac{3}{4} \\
1 \\
1 \\
1 \\
1 \\
1 \\
1 \frac{3}{4} \\
1 \frac{1}{2} \\
2\end{array}$ & $\begin{array}{r}\text { 11:30 a. m. } \\
\text { 9:30 a. m. } \\
\text { About } 12: 00 \text { m. } \\
10: 50 \text { a. m. } \\
10: 00 \text { a. m. } \\
11: 30 \text { a. m. } \\
1: 00 \text { p. m. } \\
\text { 10:20 a. m. } \\
10: 00 \text { a. m. }\end{array}$ & $\begin{array}{r}3: 00 \text { p. m. } \\
3: 30 \text { p. m. } \\
4: 30 \text { p. m. } \\
4-26-8: 00 \text { a. m. } \\
4: 00 \text { p. m. } \\
4: 30 \text { p. m. } \\
4-13-4: 00 \text { p. m. } \\
4: 00 \text { p. m. } \\
4-22-8: 00 \text { a. m. } \\
4-28-8: 00 \text { a. m. }\end{array}$ & 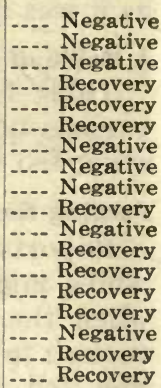 \\
\hline
\end{tabular}

\section{Symptoms Exhibited by Poisoned Cattle.}

Slobbering was not so common a symptom in cattle as in sheep, while vomiting was much more common and more profuse. This vomiting made the animals appear very thin until they recovered sufficiently to eat. A rise in the rate of respiration was a common symptom. Severely poisoned cattle became very weak and dull; the gait was unsteady, particularly in the hind-legs, the animals sometimes stumbling with the hind feet. A few were either so weak that they were unable to get up, or else they would fall over when walking. Grinding of the teeth and diarrhea were each observed in a single animal.

\section{Length of Time Required for Symptoms to Appear in Cattle.}

The time from the middle of the feeding period until cattle became sick varied from 20 minutes to $2 \frac{1}{2}$ hours, averaging about 1 hour and 7 minutes. They remained sick for from 3 to 22 hours, averaging $11 \frac{1}{2}$ hours.

\section{Some Typical Cases of Death Camas Poisoning in Cattle.}

Case 1. A calf weighing 165 pounds was fed $\frac{3}{8}$ of a pound of death camas leaves at 9 a. m., April 10, 1919. At 11:30 it was sick and vomited freely. It remained sick, vomiting frequently, until 1:30. At $3 \mathrm{p} . \mathrm{m}$. it appeared to have recovered.

Case 2. A calf weighing 150 pounds was fed $\frac{1}{2}$ pound of the leaves at 10:50 a. m., April 23, 1919. It vomited between noon and $1 \mathrm{p} . \mathrm{m}$. At $3 \mathrm{p}$. m. it was lying down and appeared dull. When made to get up it walked with an unsteady gait. At $5 \mathrm{p}$. m. it was up and eating hay. At 8 a. m. next day it was still slobbering; but by $5 \mathrm{p}$. m. it had apparently recovered.

Case 3. A calf weighing 208 pounds was fed one pound of death camas at 9 a. m., April 8, 1919 . At 10 a. m. it began vomiting and frothing slightly at the mouth. At 11:20 it was breathing at the rate of 94 times per minute. At $2: 45$ it had stopped vomiting and the respiration had fallen to 34 per minute. The animal was still slightly sick at $3: 30 \mathrm{p}$. m. but was eating, and appeared to have nearly 
recovered at $4: 30 \mathrm{p}$. m. At $8: 30$ next morning it was walking with a peculiar gait, frequently stumbling with the hind feet.

Case 4. A calf weighing 208 pounds was fed $1 \frac{1}{2}$ pounds at 10 a. m., April 19, 1919. At 10:20 a. m. it began vomiting, and vomited again at $11: 20$ a. m. Was grinding the teeth almost constantly from 10:30 until noon. At noon the respiration was 40 per minute. This calf was able to get up at $2 \mathrm{p}$. m., but walked with a very unsteady gait, especially noticeable in the hind legs. This condition continued until $9: 30$ p. m. At 80 'clock next morning it was still weak and looked very thin.

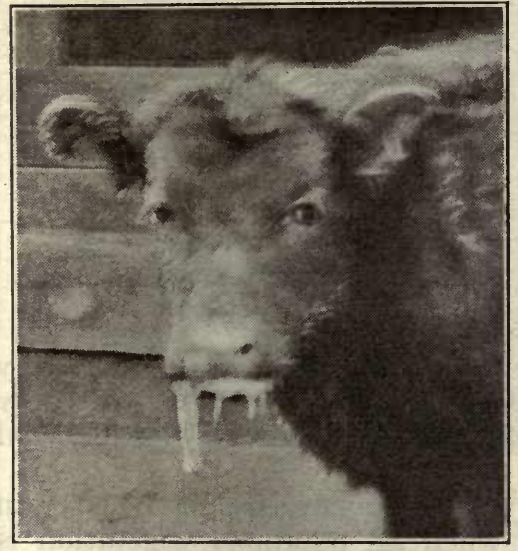

Figure 9. Death Camas Poisoning. This ealf shows slobbering after eating death camas. This symptom is more common in sheep than in cattle.

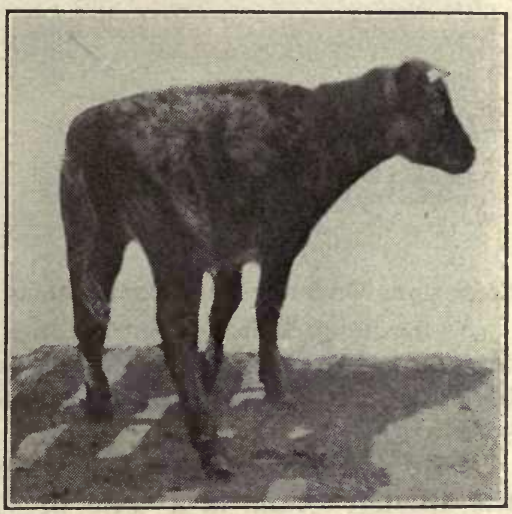

Figure 10. Death Camas Poisoning. This calf shows a common symptom-weakness in the hind-legs.

It ate a little hay, but soon quit; the bowels were quite loose. At 8 a. m. on April 22, it appeared to have recovered; but was still thin and a little dull.

Case 5. A calf weighing 193 pounds was fed two pounds of death eamas leaves at $9: 30 \mathrm{a} . \mathrm{m}$. At $10 \mathrm{a}$. $\mathrm{m}$. it began to slobber, the respiration then being 56 per minute. It vomited between noon and $1 \mathrm{p} . \mathrm{m}$. At 3 p. m. it was still dull, and walked with an unsteady gait when made to get up. Next morning it appeared to have fully recovered.

\section{Meadow Death Camas, Feeding Tests with Cattle.}

Owing to the scarcity of material, few tests were made with this species. The five feedings made are summarized in Table VI.

\section{TABLE VI}

Meadow Death Camas (Z. venenosus). The Green leaves fed to Cattle.

\begin{tabular}{|c|c|c|c|c|c|c|c|}
\hline $\begin{array}{c}\text { Animal } \\
\text { No. }\end{array}$ & $\begin{array}{l}\text { Weight } \\
\text { lbs. }\end{array}$ & Date fed & Time fed & $\begin{array}{l}\text { Amount } \\
\text { fed. lbs. }\end{array}$ & $\begin{array}{c}\text { Time symptoms } \\
\text { appeared }\end{array}$ & $\begin{array}{l}\text { Time of death } \\
\text { or recovery }\end{array}$ & Final result \\
\hline $\begin{array}{r}8 \\
9 \\
1 \\
10 \\
8 \\
\hdashline \ldots \ldots\end{array}$ & $\begin{array}{l}220 \\
235 \\
138 \\
330 \\
220\end{array}$ & $\begin{array}{l}6-11-19 \\
6-11-19 \\
6-11-19 \\
6-11-19 \\
6-12-19\end{array}$ & $\begin{array}{l}2: 00 \text { p. m. } \\
2: 30 \text { p. m. } \\
11: 45 \text { a. m. } \\
2: 40 \text { p. m. } \\
8: 45 \text { a. m. }\end{array}$ & $\begin{array}{r}\frac{3}{8} \\
\frac{1}{2} \\
\frac{8}{8} \\
1 \\
1 \frac{1}{8}\end{array}$ & $\begin{array}{l}12: 45 \mathrm{p.m} \\
1: 00 \mathrm{p.m}\end{array}$ & 2:40 p. m. & $\begin{array}{l}\text {... Negative } \\
\text { Negative }\end{array}$ \\
\hline
\end{tabular}


Summary of Results of Feeding Death Camas to Cattle.

Table VII shows graphically the effect of various amounts of death camas when fed to cattle in experimental tests.

TABLE VII

Death Camas (Z. paniculatus and Z. venenosus). Summary of Srmptoms, Feeding Experiments with Cattle.

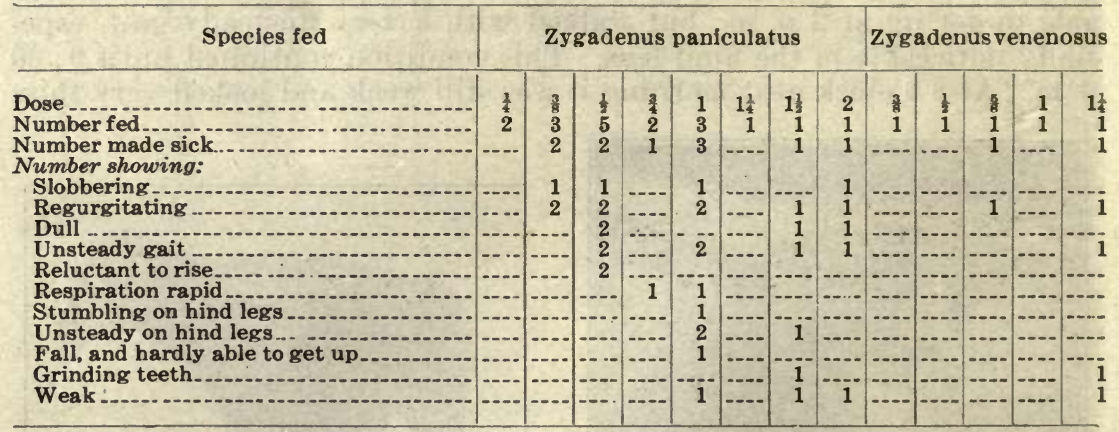

Conditions Under Which Death Camas Poisoning Is Most Likely to Occur.

As has been stated, death camas contains a bitter substance extremely distasteful to both sheep and cattle. Consequently the plant is eaten by these animals only under stress of extreme hunger or prolonged starvation.

Most of the cases of death camas poisoning have occurred early in the spring. This is a time of year when all palatable vegetation is scarce, and range animals are often poor and hungry, depending of course upon the way in which they have been handled during the winter. Under these conditions, on a range supporting very little palatable vegetation, hungry animals will eat almost any plant in order to satisfy their hunger. This is well illustrated by a loss of cattle which took place in Elko County.

A herd of cattle were being trailed through sagebrush country where the grass and weeds were just beginning to grow, but where a considerable number of death camas plants had already made their appearance. The cattle were thin and hungry, and at every opportunity they bit off the death camas plants. A rather large number of cattle died as a result of this drive. Some of the poisoned animals that were left behind recovered; those that were driven hard in most cases died on the trail.

In regard to cattle, then, it may be said that the following are the range conditions under which death eamas poisoning is most likely to occur: (1) When hungry stock are unloaded from the cars in spring and turned out on a depleted range where death camas is common, and there is very little grass; (2) When cattle are trailed from one range to another in the spring when all palatable feed is scarce; (3) When hungry animals in poor condition are turned out to rustle for themselves in the early spring before the grass is up, so that they are forced to graze any and all plants in order to satisfy their hunger.

When sheep are grazing openly and quietly on a range, they show great care in the selection of the forage they eat. However, when they are being trailed from one place to another, they have no chance to 
choose what they will eat, with the result that they eat anything that is not absolutely repellant. If death camas is common, and it usually is, they eat so much of it that they get more of the poison than they can throw off. They are constantly forced to move along on the trail by dogs and herders, and death naturally follows.

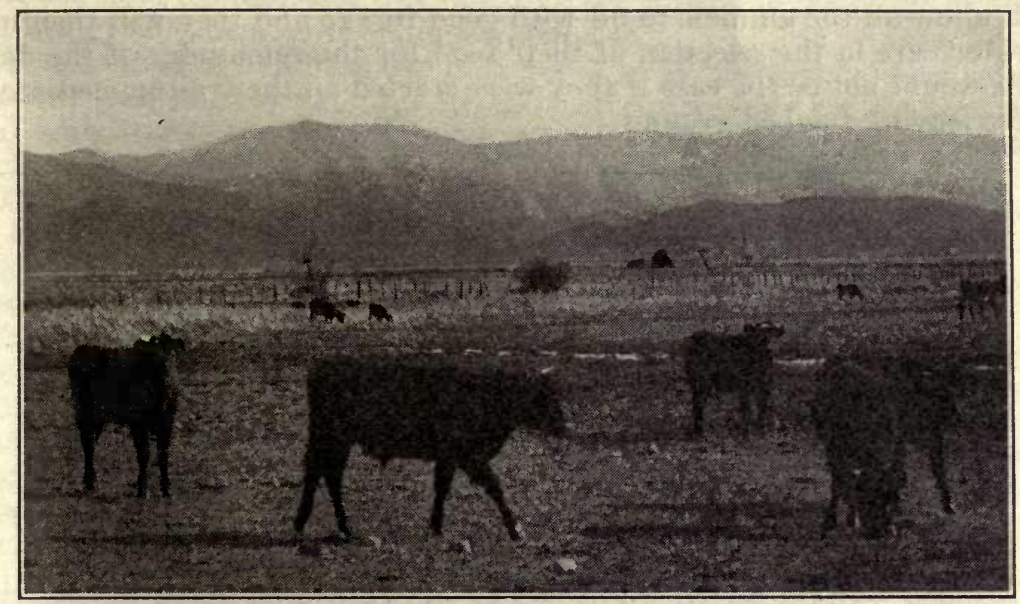

Figure 11. Thin and Hungry Cattle on Poor Pasture. Early in the spring animals in this condition are ravenous for green feed. They will then eat death camas or other poisonous plants which ordinarily they would not touch.

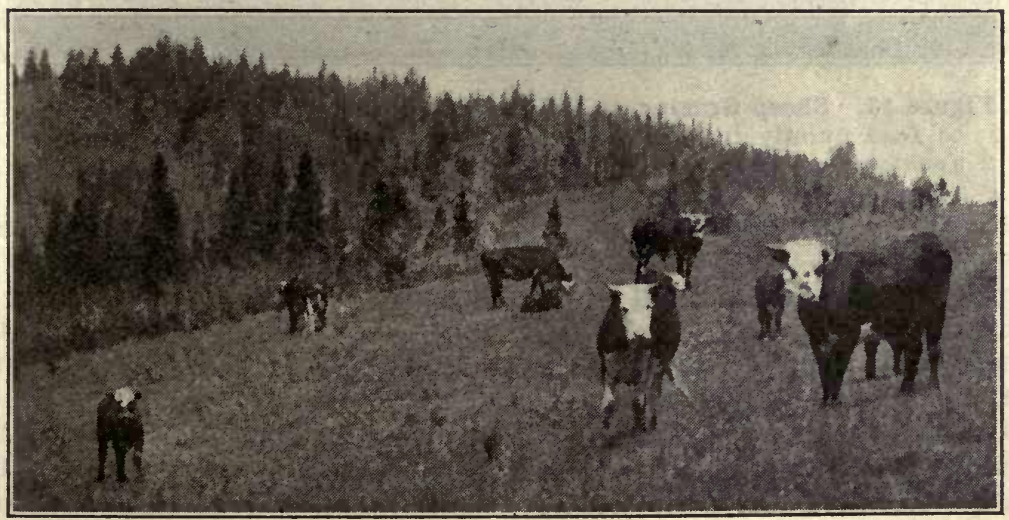

Figure 12. Cattle on Good Mountain Pasture. Well-fed animals on good range will ordinarily avoid poisonous plants almost wholly.

It should always be remembered that when a sheep is hungry it usually eats greedily the plant on which it is feeding, or else rushes to another plant for fear some other sheep will get there before it does. But when sheep are grazing openly and quietly, they nip off only the tender and juicy parts of the plant, the leaves and young stems, and carefully select the plants on which they feed. 
How to Avoid Death Camas Poisoning in Sheep and Cattle.

Evidently in order to avoid losses on a range where death camas is common, sheep should be so handled that they are never bunched up nor extremely hungry. If they are to be driven from one range to another, it is best to allow them to graze for an hour or two in the morning just as openly and quietly as possible before starting to move them. This will allow all the animals to fill with good forage and they will then use greater care in the selection of their food for the remainder of the day. This would not be the case if they were started on the trail immediately after leaving the bed-ground.

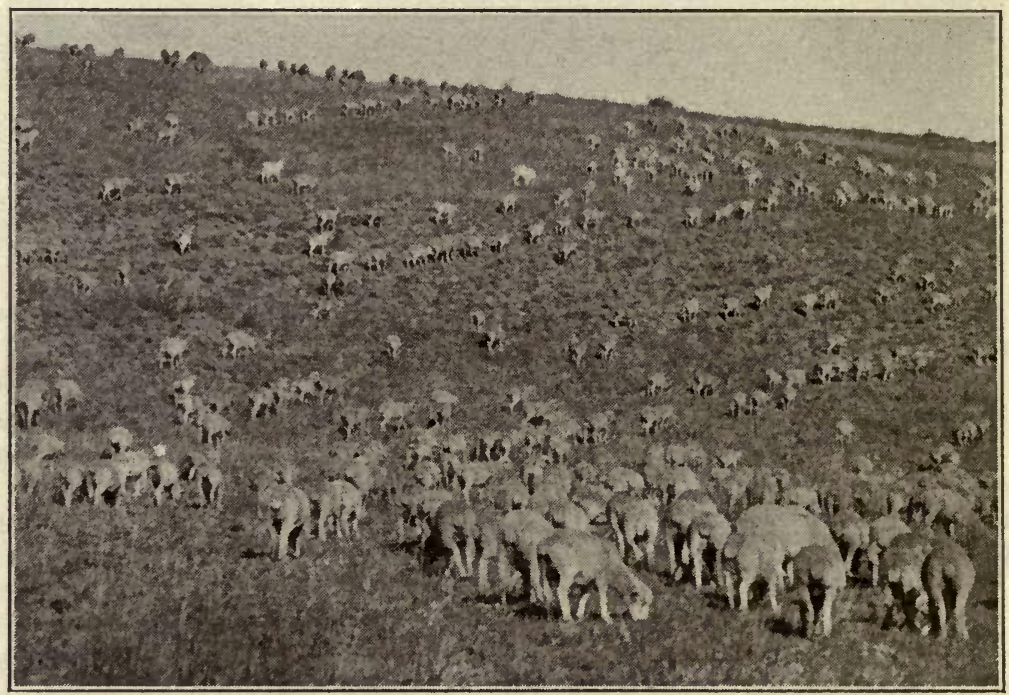

Figure 13. Sheep Grazing at Will on Sagebrush Range. When allowed to feed quietly in scattered formation, sheep will ordinarily wholly avoid death eamas and many other poisonous plants.

Another very important point is to get the sheep off the bed-ground just as early in the morning as possible. When a sheep beds down at night it is usually full and contented. By morning it is beginning to get rather empty, and the longer it is kept on the bed-ground the hungrier it becomes; it is then far more apt to be poisoned when it gets out on the range where the death camas is common.

In most of the cases of death camas poisoning thus far observed, the animals were poisoned during the forenoon. This is due to the fact the attractiveness of the plant decreases as the stomach becomes full. Thus plants which may seem to be highly palatable and to be relished during the morning hours are often not touched at all later in the day. This is quite true of the death camas. It is grazed chiefly during the early morning hours, and is seldom touched by an animal whose stomach is nearly full. Therefore it is highly important that the sheep should be so handled during the early morning hours that they will have the greatest freedom in the selection of their range forage; if possible, during this part of the morning they should be grazed on range free from death camas, or where it has only a very scattering growth. 
In Nevada the prevailing method of handling sheep, especially in the spring of the year, is to establish a main camp from which the sheep are grazed daily until all the feed in the immediate vicinity of the camp has been eaten out to a distance of two or three miles in every direction. This requires long daily drives back and forth in order to get away from range that has already been grazed. Thus the sheep trail over the same ground each day, until all the forage on the range around the bed-ground has been completely eaten off.

This method of handling can only result in all the plants being eaten, whether poisonous or not; for the most attractive ones are first grazed, and when these are gone the less palatable ones are left to be eaten, including, of course, the death camas.

In order to avoid the losses which result from such improper methods of handling sheep, they should be allowed to bed down wherever they happen to be when night comes. They will then always be on fresh feed in the morning. The variety of forage from which to choose will be much greater; and the probability of poisoning will be far less; providing, of course, that the animals are gotten off the bed-ground early in the morning and are allowed to spread out and graze openly and quietly, each ewe with her lamb. Close-bunched grazing, running, trailing, and massing should be avoided; not only to reduce losses from poisonous plants, but also for the good of the ewe and her lamb, and for the most full and effective use of the range forage.

Remedies for Death Camas Poisoning.

For animals poisoned by death eamas there is known at present no practical remedy. The best treatment is to let the poisoned animals entirely alone, disturbing them only when it is absolutely necessary. After an animal has been poisoned it is very much weakened and should be given all the eare that is practicable on the range. If it can be kept on good feed and driven just as little as possible for the first two or three days, it will often recover rapidly. 


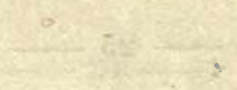

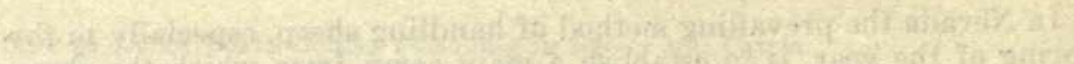

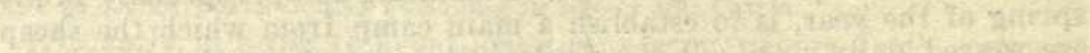

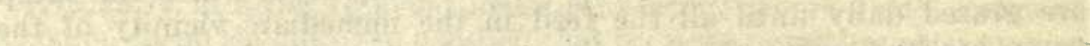

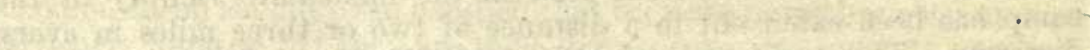

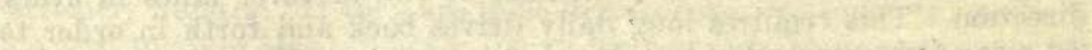

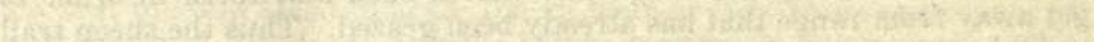

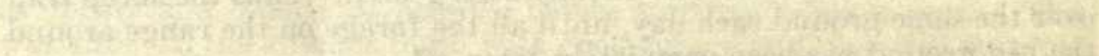

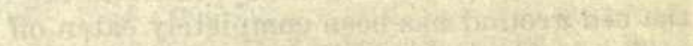

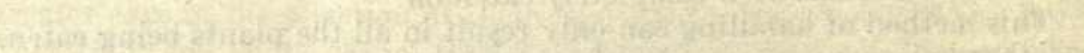

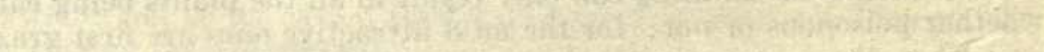

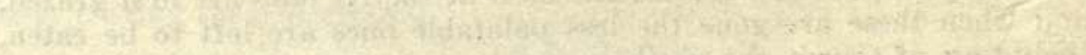

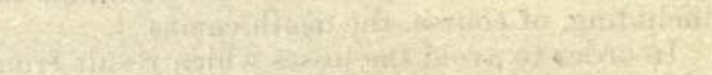
Wayt Herat.

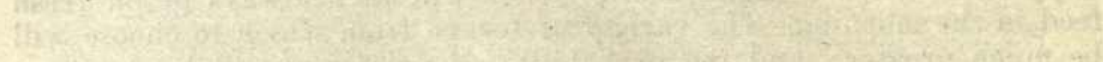




\section{SECTION II}

The material included in this section is of greater interest to chemists and veterinarians than to livestock owners. 



\section{POST-MORTEM CONDITIONS}

Autopsies upon six sheep whose death was caused by death camas in feeding experiments showed the following post-mortem conditions :

There appeared to be no outstanding lesions which would serve to indicate a characteristic effect due to poisoning by this plant. On the whole, the lesions shown were those of a general toxemia. The conditions were such as are found more or less uniformly, with individual variations, after death caused by the ingestion of various toxic or semitoxic plants.

Various degrees of congestion in the gastro-intestinal tract and in its lymphatic system appeared to be prominent symptoms. In some instances the same condition was also found in the kidney, spleen, and liver. The lungs appeared to show no change. In some cases the heart displayed small hemorrhages beneath the epicardium and endocardium, characteristic of toxemia. Considerable quantities of free fluid were observed in the thoracic and abdominal cavities.

\section{THE ACTIVE PRINCIPLE OF DEATH CAMAS}

It has long been known that alkaloids are partially, if not wholly, responsible for the poisonous properties of the death camas. Different investigators have studied various species of Zygadenus, and the lack of uniformity in the results obtained is not surprising. In the bulk of the work reported it is stated that alkaloids have either been isolated or detected; a single worker found resins in the plant which had poisonous properties. Later attempts to verify these findings in closely related species resulted in failure.

Two physiologically active resins were found by Vejux-Tyrode in 1904 in the bulbs of Zygadenus venenosus from Montana. From one of the resins he isolated a basic body which he designated zygadinein and an acid-zygadenic acid. In animal experiments he found the zygadinein to be the active principle. When given in minute doses to guinea pigs, rabbits, and dogs it produced salivation, staggering and respiratory paralysis followed by death, in some cases in a few minutes but usually within a few hours. In 1913 the chemists of the Wyoming Station, F. W. Heyl and F. E. Hepner, investigated Zygadenus intermedius for similar toxic resins, but were unable to isolate any toxic substance from the resin or even to establish the toxicity of the resin itself.

The work of early investigators consisted of color tests made upon impure products and led to conclusions that the alkaloids in the species tested belonged to the veratrine group.

In 1903 George Heyl obtained an alkaloid from a California species of Zygademus. The alkaloid found amounted to $0.4 \%$. It was soluble in ether and nearly insoluble in water. Its melting point was $134-135^{\circ}$. It formed a crystalline hydrochlorid.

Alkalodial analyses of Zygadenus intermedius were made in Wyoming in an endeavor to determine the quantity of alkaloidal material present in the different parts of the plant. On account of the lack of suitable methods for the determination, the results are probably not so 
accurate as might be desired and show only a fair degree of uniformity. Figures for the amounts found in the dried leaf varied from $0.57 \%$ to $0.66 \%$; bulb, $0.188 \%$ to $0.57 \%$; flower, $1.07 \%$ to $1.35 \%$; root, $0.306 \%$ to $0.32 \%$.

A quantity of material was prepared and submitted to Dr. Phillip Mitchell and Mr. Geo. Smith for toxicological experiments. The material used in these experiments was not the more highly purified crystallized alkaloid which was reported on later. It was found that when injected intraperitoneally a quantity between $4.6 \mathrm{mg}$. and $5.1 \mathrm{mg}$. would produce death in a guinea pig. When administered by mouth a comparatively large quantity was required for fatal effects in the guinea pig. The larger amount necessary was partially accounted for by the fact that the material caused vomiting. In the guinea pig the effects of the material appeared to be the same after subcutaneous or intraperitoneal injection or after feeding.

The mixed alkaloids cause vaso-dilatation and apparently affect the cardio-inhibitory center, slowing the heart action. Respiration was slowed. After doses approaching the fatal quantity the heart-beat becomes rapid and irregular and there is convulsive respiration. In dogs the fatal dose given intravenously stopped the heart before respiration ceased. When either injected or fed, it had a powerful action both as a purgative and an emetic.

Later, in the Wyoming experiments, a more highly purified alkaloid was obtained which could be crystallized from alcohol and benzene. The crystalline material from benzene melted at $200-210^{\circ}$ and was found to have the formula $\mathrm{C}_{39} \mathrm{H}_{63} \mathrm{NO}_{10}$. The physiological action was tested by Dr. Phillip Mitchell, who reported its effects to be different from those found for the mixed alkaloids. Its behavior was in general much like the alkaloid veratrine and it required comparatively large quantities to kill guinea pigs. Unlike the mixed alkaloids it had no noteworthy effect on the heart and apparently caused complete loss of muscular control.

In 1918 Dr. C. A. Jacobson of the Nevada Station reported obtaining a new alkaloidal product from $Z$ ygadenus paniculatus. This alkaloidal product was designated by him as "Z-alkaloid." The crude alkaloid was prepared by extracting the ground and dried plant with $95 \%$ alcohol, concentrating the extract to a sirup and pouring into a dilute solution of tartaric acid to remove resins and other impurities. The clear acid solution was further purified by extraction with ether; and the crude alkaloid was precipitated by the addition of sodium carbonate. The precipitate was an amorphous sticky mass poisonous to rabbits. The liquid containing the precipitated solid matter was extracted with ether. It was found that if the ether was completely removed on the water bath, the material would then undergo violent effervescence and the resulting product would no longer be poisonous. If, however, the last of the ether was allowed to evaporate in the air at ordinary temperatures no effervescence took place and the resulting material retained its potency. Further purification was effected by re-solution in tartaric acid, removal of impurities with ether, neutralization and extraction with ether and chloroform.

The more purified Z-alkaloid had an increased toxicity, about 0.35 gram being found to be lethal for rabbits when administered by mouth. 
The Z-alkaloid, which constituted about $0.3 \%$ of the dried plant, was soluble in ethyl and methyl alcohol, chloroform, acetone, and less so in benzene and carbon tetrachlorid. On standing several months, it resinified to a white substance without change in its toxicity or solubility. On long standing, an alcohol-insoluble crystalline material separated to the extent of about $1 \%$ of the original mass, but on account of the small quantity obtained its physiological action could not be determined. Various compounds of the Z-alkaloid were prepared; and from the data obtained it appeared that it is not the same as the compound named Zygadinein which was obtained at the Wyoming station. 
RETURN TO the circulation desk of any

University of California Library

or to the

NORTHERN REGIONAL LIBRARY FACILITY

Bldg. 400, Richmond Field Station

University of California

Richmond, CA 94804-4698

ALL BOOKS MAY BE RECALLED AFTER 7 DAYS

2-month loans may be renewed by calling (415) 642-6753

1-year loans may be recharged by bringing books to NRLF

Renewals and recharges may be made 4 days prior to due date

DUE AS STAMPED BELOW AUG 081990

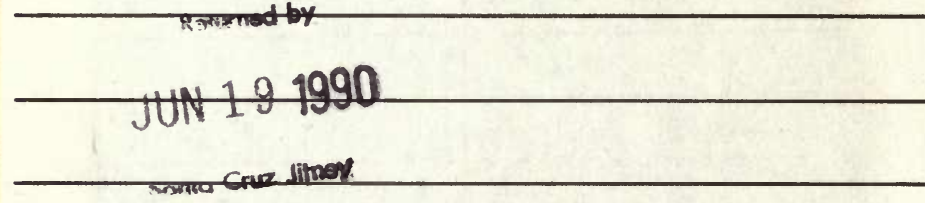




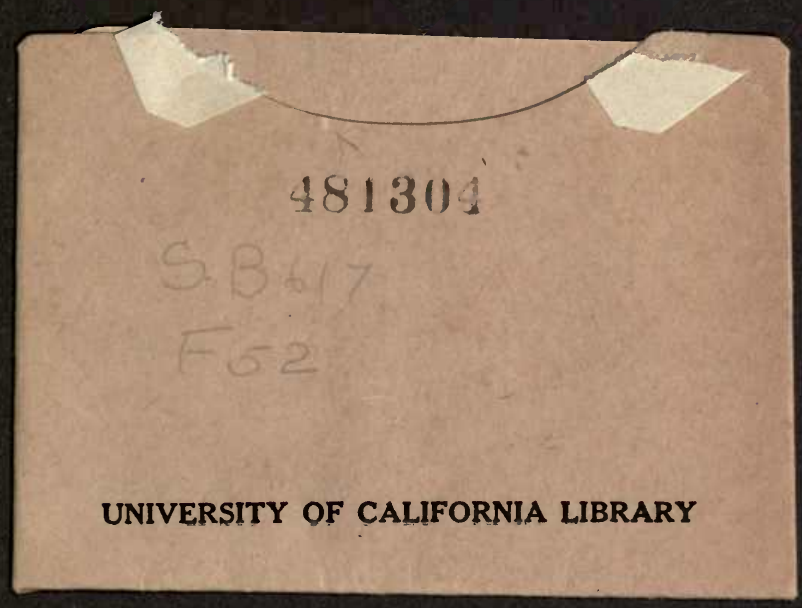

UNIVERSITY OF CALIFORNIA LIBRARY 
